\title{
Novel Intrapleural Therapies for Malignant Diseases
}

\author{
Andrew R. Haas Daniel H. Sterman \\ Section of Interventional Pulmonology and Thoracic Oncology, Pulmonary, Allergy, and Critical Care Division, \\ Department of Medicine, University of Pennsylvania Medical Center, Philadelphia, Pa., USA
}

\section{Key Words}

Extrapleural pneumonectomy · Malignant mesothelioma • Malignant pleural effusion

\begin{abstract}
Pleural malignancies, either primary or metastatic, are common and problematic clinical issues in thoracic oncology and pulmonary medicine. Malignant pleural mesothelioma and metastatic pleural effusions often present late in the course of a disease and have a dramatic impact on the patient's quality of life and survival. Novel approaches to manage mesothelioma and malignant pleural effusions are desperately needed and the pleural space provides a unique platform as an easily accessible body cavity for developing and assessing these treatments and their responses. In this review, we discuss the unique intrapleural chemotherapeutic, immunotherapeutic and genetic treatments that have been investigated, as well as those under current clinical development. While responses have been demonstrated to variable degrees with all these approaches, an integrated multimodality approach incorporating these methods with other anti-neoplastic interventions ultimately will ensure the best responses and patient outcomes.
\end{abstract}

Copyright ๑ 2012 S. Karger AG, Basel (c) 2012 S. Karger AG, Basel 0025-7931/12/0834-0277\$38.00/0

Fax +41613061234 E-Mail karger@karger.ch www.karger.com
Accessible online at:

www.karger.com/res

\section{Introduction}

Pleural malignancies, both primary and metastatic in origin, are notoriously refractory to treatment despite multiple clinical trials of combinations of surgical resection, systemic chemotherapy, external beam radiation therapy, and other interventions. The unique aspect of pleural malignancies such as mesothelioma is that they develop in a body cavity that is readily accessible for examination, biopsy, and repeated fluid sampling. Therefore, any novel therapeutic that is of interest in the treatment of pleural malignancies can be studied in a directed fashion with intracavitary delivery and rapid read-out of both positive effects and complications. The fact that many pleural malignancies, and mesothelioma in particular, cause morbidity and even mortality by local spread within the ipslateral hemithorax provides another rationale for delivery of novel therapeutics directly into the pleural space [1].

Previous articles in this series: 1. Anevlavis S, Tzouvelekis A, Bouros D: Mechanisms of pleural involvement in orphan diseases. Respiration 2012;83:5-12. 2. Rodriguez-Panadero F, Montes-Worboys A: Mechanisms of pleurodesis. Respiration 2012;83:91-98. 3. Grundy S, Bentley A, Tschopp JM: Primary spontaneous pneumothorax: a diffuse disease of the pleura. Respiration 2012;83:185-189.
Daniel H. Sterman, MD

Section of Interventional Pulmonology and Thoracic Oncology, Pulmonary, Allergy, and Critical Care Division, University of Pennsylvania Medical Center 833 West Gates Building, Philadelphia, PA 19104-4283 (USA)

Tel. +1 215614 0984, E-Mail daniel.sterman@uphs.upenn.edu 
The concept of intrapleural (IP) therapy for thoracic malignancies ironically arose from observations of the effects of one complication of surgical resection for nonsmall cell lung cancer - contamination of the pleural space resulting in postoperative empyema. In the early 1970s, several groups reported improved survival in patients who developed postoperative empyema compared to similarly matched postoperative patients without pleural infection [2-4]. The theory was posited that the inflammatory environment of the empyema would recruit lymphocytes to the pleural space engendering an antitumor immune response that could improve disease control and survival, although this was not borne out in larger case series [5-7]. Based upon these early studies, the hypothesis was generated that the pleural space could be utilized as an ideal access point for the induction of immune responses against advanced lung cancer, primary pleural tumors such as malignant mesothelioma (MM), and metastatic pleural neoplasms.

Based on these early reports that postoperative empyema may improve lung cancer survival, several groups investigated the hypothesis that Bacillus CalmetteGuérin (BCG) injection into the pleural space would initiate a nonspecific immune response that could generate anti-tumor immune effects similar to those of empyema without the associated complications of severe pleural space infection. One early study randomized patients to a single dose of IP BCG versus saline instillation after resection of primary lung cancer and showed a potential survival advantage in stage I disease [8]. Based upon these encouraging results, several larger randomized trials were undertaken. Unfortunately, none of these trials demonstrated a survival advantage of adjuvant IP BCG compared to controls $[9,10]$. Based on the results of these studies, further investigations into IP BCG as adjuvant therapy for lung cancer were not pursued; however, the concept of using the pleural space as a site of delivery of novel therapeutics to treat primary or metastatic pleural malignancies has remained. These investigations have been pursued in three major areas: IP chemotherapy, IP immunotherapy, and IP gene therapy. We will consider each of these three treatment modalities separately.

\section{IP Chemotherapy}

Mesothelioma, thymomas, and thymic carcinoma are tumors of the thoracic cavity that are notorious for locoregional spread of disease as opposed to distant metastases. Although surgical resection can be attempted, the presence of residual microscopic disease is virtually guaranteed for MM and thymic carcinoma. Therefore, many groups have investigated whether local control of these malignancies can be achieved by instilling chemotherapeutic agents into the pleural space (IP) either alone or in combination with surgical debulking of the primary tumor. Once such example is a study by Refaely et al. [11], published in 2001, in which the authors reported their experience with IP chemotherapy in 15 patients who had either thymic carcinoma $(n=5)$ or thymoma $(n=10)$. These patients all underwent surgical resection with intraoperative hyperthermic treatment with cisplatin. One patient with thymic carcinoma was alive at 54 months and 8 patients with thymoma were alive without evidence of recurrence at 9-70 months. While 2 patients developed significant bleeding, no other major toxicities were reported [11]. The hyperthermia was used to break down tight intracellular junctions and increase tumor cell access to cytotoxic chemotherapy.

Given the extremely poor rates of response to all therapies for pleural malignancies, some groups have attempted to develop multimodality treatment approaches involving both IP and systemic chemotherapy. For example, Pinto et al. [12] treated 22 patients with MM with IP mitoxantrone in combination with intravenous methotrexate and mitomycin. They reported 1 complete response (CR), 6 partial responses (PR), and 7 patients with stable disease. Although the overall median survival time for the entire group did not exceed the historical median survival (13.5 months), the individuals with a response did have a median survival of 18 months compared to 8 months for nonresponders. Furthermore, there were significant reductions in dyspnea (68\%) and pain (33\%) following treatment with IP chemotherapy [12].

Other groups have taken a more aggressive approach to the management of MM by utilizing extrapleural pneumonectomy (EPP) followed by IP chemotherapy to control microscopic residual disease. Chang and Sugarbaker [13] reported results of a series of clinical trials combining EPP with intraoperative hyperthermic chemotherapy with cisplatin or gemcitabine. The IP chemotherapy concentrations were higher than can be achieved by intravenous administration due to systemic toxicity; however, these studies demonstrated that these IP doses can be tolerated with acceptable toxicity [13]. More recent studies at the Brigham and Women's Hospital showed that hyperthermic intraoperative intracavitary cisplatin perfusion following EPP can be performed with acceptable morbidity and mortality, albeit with some cisplatinrelated renal dysfunction, and may enhance local control 
in the chest. Tilleman et al. [14] did show that amifostine combined with sodium thiosulfate might reduce renal toxicity associated with IP hyperthermic cisplatin perfusion.

Although MM and thymic tumors are relatively rare malignancies, metastatic disease to the pleura from other primary tumor sites (e.g. lung, breast, ovary) is much more common and is associated with significant morbidity due to dyspnea and pain and portends a poor prognosis. Consequently, many groups have investigated whether IP chemotherapy could be a modality to control malignant pleural effusions (MPE) - particularly those due to lung cancer, given its high incidence of pleural dissemination - as well as to positively impact overall survival from the primary tumor.

In 1999, Tohda et al. [15] treated 68 patients with MPE due to lung cancer with single-dose IP cisplatin and etoposide with minimal systemic toxicity. The overall response rate (control of effusion) was $46.2 \%$, the median survival time 32.3 weeks, the 1 -year survival rate $28.7 \%$, and the 2-year survival rate $12.8 \%$. A more frequent dosing regimen was pursued by Shoji et al. [16] via placement of an indwelling pleural catheter for the biweekly IP instillation of 5-flourouracil and cisplatin in 22 patients with MPE. They demonstrated the safety of this approach, and a median survival period of 403 days. This study suggested that repeated IP chemotherapy may be more advantageous than single-dose IP therapy.

$\mathrm{Su}$ et al. [17] reported a more extensive combination therapy approach wherein 27 patients with MPE secondary to bronchogenic carcinoma received sequential treatment with IP cisplatin followed by intravenous gemcitabine, thoracic irradiation, and intravenous docetaxel. The overall response rate was 55\% with 7\% CR. Remarkably, only 2 of 27 patients experienced recurrence of pleural effusion, and the 1-year survival was $63 \%$ [17]. To ascertain whether IP chemotherapy actually had an effect on malignant cells in the pleural space, Matsuzaki et al. [18] resected primary pulmonary adenocarcinoma in 11 consecutive patients with pleural dissemination and subsequently treated them with IP cisplatin. They collected pleural fluid before and after treatment, isolated malignant cells, and stained them to determine the degree of induced apoptosis. The investigators demonstrated a dramatic increase in the number of apoptotic cells in patients treated with IP cisplatin versus patients who had surgical resection alone ( 25.2 vs. $2.8 \%$, respectively). In addition, while the median survival time for patients receiving the perfusion treatment was 20 months, the median survival time for the control group was 6 months [18]. Therefore, not only did IP chemotherapy appear to have a survival advantage but there was also evidence that IP therapy could significantly increase apoptosis of malignant cells in the pleural space.

More recently, studies of IP chemotherapy have been conducted with agents that may have greater efficacy in metastatic pleural disease, particularly of lung origin. One such trial was conducted recently by Jones et al. [19] from the University of Virginia. They designed a phase I dose escalation study to determine the maximum tolerated dose of IP docetaxel administered through an implantable catheter in 15 patients with MPE. Subjects with MPE were enrolled into four single-dose levels of docetaxel administered IP after drainage of the pleural effusion and insertion of an IP catheter. All patients tolerated the therapy well and there were no significant toxicities. The majority of patients had a complete radiographic response, including all patients receiving an IP dose of 100 $\mathrm{mg} / \mathrm{m}^{2}$ or higher. Pharmacokinetic data demonstrated a peak plasma concentration of docetaxel between $30 \mathrm{~min}$ and $6 \mathrm{~h}$ after infusion. Pleural exposure to docetaxel was 1,000 times higher than systemic exposure, which likely accounted for the minimal systemic toxicities seen [19]. This study confirmed the safety and efficacy of IP chemotherapy in malignant pleural disease and suggested that larger, randomized trials were warranted in this population.

\section{IP Immunotherapy}

The immune system is an extremely complex network with multiple levels of control, regulation, and coordination that balances prevention of autoimmunity with facilitation of recognition and destruction of foreign antigens. For many years, the prevailing theory held that neoplasms averted an immunologic response because they were derived from normal tissue and thus they were not recognized by the immune system. With the advent of genomics and proteomics, it has become evident that tumor cells differ substantially in many ways from normal cells and that the immune system does recognize these aberrant tumor cells. Unfortunately, at multiple levels, the tumor and its microenvironment suppress the ability of the immune system to mount any effective anti-tumor response. With this new understanding of the immunologic processes involved in cancer, many groups have investigated the possibility of enhancing the immunologic response against MM or metastatic pleural tumors by IP instillation of immunostimulatory agents. 
Like many human malignancies, $\mathrm{MM}$ has been thought to be resistant to mechanisms of immune-mediated destruction. In more classically 'immunogenic' tumors, such as malignant melanoma or renal cell carcinoma, immunotherapy via exogenous cytokines, monoclonal antibodies, and tumor vaccines has demonstrated some significant responses. Immunotherapy has been applied to MM despite the observations that MM cells induce intratumoral downregulation of cellular, cytokine, and humoral immune responses, which might significantly inhibit any approaches to augment the antitumor immune response [20]. In particular, high levels of TGF- $\beta$ elaborated by mesothelioma cells and tumor-infiltrating macrophages cause downregulation of $\mathrm{CD} 3$ molecules on the cell membrane of tumor-infiltrating $\mathrm{T}$ lymphocytes as well as an influx of regulatory $\mathrm{T}$ cells, leading to a state of immunologic tolerance $[21,22]$. Mesothelioma cells express abundant class I major histocompatibility complex (MHC) molecules, but only small amounts of MHC class II molecules, and there is no demonstrable expression of the important co-stimulatory molecule B7-1. This results in minimal natural killer (NK) cell anti-tumor activity, poor presentation of tumor antigens to CD4 helper T lymphocytes, and inadequate stimulation of CD8 cytotoxic T lymphocytes. In addition to the tumor's innate mechanisms of immune evasion, it has been demonstrated that patients with MM have impaired immune systems: abnormal humoral and cell-mediated immunity, abnormal cell-mediated antibody-dependent cellular toxicity, and defective macrophage and NK cell function [22-25]. High local levels of certain proinflammatory cytokines may, however, be able to overcome the innate immune resistance of MM. This rationale has supported several human clinical trials demonstrating varying degrees of tumor regression with IP or systemic infusion of various cytokines, including interleukin-2 (IL-2) [26], interferon- $\alpha$ (IFN- $\alpha)$ [27], and interferon- $\gamma(\operatorname{IFN}-\gamma)[28,29]$.

It is now over 20 years since the publication by Boutin et al. $[28,29]$ of a phase I/II clinical trial assessing the activity of IP recombinant $\gamma$-interferon in MM. This landmark study involved the administration of $40 \times 10^{6} \mathrm{U}$ $(\sim 2,000 \mu \mathrm{g})$ of interferon via an implantable IP catheter twice a week for 8 weeks on an outpatient basis in $22 \mathrm{pa}$ tients with MM. Toxicity was minimal with no dose-limiting side effects. Tumor response was evaluated by chest CT scan and by repeat thoracoscopy. CR (with negative pleural biopsies) were seen in 4 of 9 patients with stage IA disease (tumor limited to the parietal and diaphragmatic pleurae). Of note, the patients who had CR all had pleural nodules less than $5 \mathrm{~mm}$ in diameter. An additional stage IA patient had a PR, for a total response rate in this group of $56 \%$. Only 1 of 10 patients with stage II disease had a $\mathrm{PR}$ and there were no CR in this group.

Based upon the encouraging results in early-stage disease in this initial trial, a prospective, multi-institutional phase II study of IP IFN- $\gamma$ in MM patients was conducted using a similar protocol [28]. Eighty-nine patients with stage I-III disease and both epithelial and mixed histologies were enrolled into the study. There were 8 histologically confirmed CR and 9 PR ( $>50 \%$ reduction in the size of the tumor). This corresponded to an overall response rate of $20 \%$ (similar to that of single-agent chemotherapy in MM) but a response rate of $45 \%$ in patients with stage I disease (tumor involving the pleural surfaces only). Patients with stage IA disease had a response rate of $61.5 \%$ with a 2.5 -year survival rate of $71 \%$, which was remarkable for this invariably fatal disease. The median survival among all stage I patients was 28 months. The constellation of toxicities was similar to that seen in the pilot study, with the most serious complication being empyema in 7 of 89 patients, 6 of whom required removal of the pleural catheter. Fourteen patients required temporary interruption of therapy because of toxicity, with 12 patients necessitating treatment stoppage secondary to various complications.

In an adjunctive study, the pharmacokinetics of IP IFN- $\gamma$ in pleural fluid and blood were measured in 6 patients [30]. Twenty-four hours after subcutaneous injection, the maximum level of IFN- $\gamma$ observed in pleural fluid was $1.14 \mathrm{U} / \mathrm{ml}$, whereas the maximal pleural fluid IFN- $\gamma$ level seen $24 \mathrm{~h}$ after IP infusion was $10,891 \mathrm{U} / \mathrm{ml}$. By 96 hours after a single IP injection, pleural IFN- $\gamma$ levels decreased slowly to $173 \mathrm{U} / \mathrm{ml}$. Corresponding serum levels of IFN- $\gamma$ after IP injection were 'low'. This study clearly demonstrated that significantly higher levels of immunostimulatory cytokines can be achieved in the pleural space by direct instillation as opposed to intravenous administration with likelihood, therefore, of decreased systemic toxicity of cytokine therapy.

The availability of IFN- $\gamma$ for clinical use in Europe limited further study, but a pilot study of IP IFN- $\gamma$ for MPE secondary to lung carcinoma was conducted in Japan [31]. Six patients with MPE underwent 1-3 weekly instillations of IFN- $\gamma$ via a pleural catheter at doses of $1-12 \times 10^{6} \mathrm{U}$. Two of the 6 patients had complete clearance of malignant cells from their pleural fluid. An additional patient had a partial radiographic response after 2 IP instillations of $4 \times 10^{6} \mathrm{U}$ of IFN- $\gamma$. No significant toxicities were noted. Pleural IFN- $\gamma$ levels averaged ap- 
proximately $5 \times 10^{6} \mathrm{pg} / \mathrm{ml} 24 \mathrm{~h}$ after IP injection; serum levels were in the range of $5 \times 10^{1} \mathrm{pg} / \mathrm{ml}$. Interestingly, IFN- $\gamma$ infusions did not, however, induce effective pleurodesis [31].

European phase I-II clinical trials of IL-2 administered by continuous infusion via a subcutaneous pleural catheter demonstrated a 19\% PR rate with significant dose-related toxicity, primarily the development of empyemas [32]. Of note were the high IP:systemic ratios of IL2 , approaching 1,000:1 in the highest dose level $[26,32]$. Researchers at the University of Turin (Italy) conducted a clinical trial involving combined systemic and IP IL-2. At interim analysis in 1997, thirty-one patients had been enrolled with a response rate of $22.5 \%$, although $90 \%$ of patients demonstrated significant reductions in pleural effusion. Toxicities were minimal, primarily fever, eosinophilia, and mild cardiac and neurologic side effects [32].

In one of the only prospective, randomized trials comparing IP chemotherapy to IP immunotherapy, Sartori et al. [33] compared IP bleomycin versus IP IFN- $\alpha 2 b$ in patients with recurrent, clinically significant MPE. While there was no significant difference in median survival (bleomycin, 96 days; IFN- $\alpha 2$ b, 85 days), the 30-day response was $84.3 \%$ in the bleomycin arm and $62.3 \%$ in IFN- $\alpha 2 b$ arm $(\mathrm{p}=0.002)$, and the median time to progression was 93 days in the bleomycin group and 59 days in the IFN- $\alpha 2 b$ group $(p<0.001)$. This study suggested that IP chemotherapy with bleomycin was superior to IP immunotherapy with IFN- $\alpha 2 b$ in control of MPE; however, there was no survival advantage, but there was a palliative advantage in terms of MPE control.

In addition to the 'specific' immunotherapeutic agents, other investigators have attempted to stimulate a broad immune activation within the pleural space using 'nonspecific' immunostimulatory agents (similar to the effect of BCG) to treat pleural malignancy. These include inactivated bacterial superantigens from streptococcus (OK432) or staphylococcus, which were studied in combination with other treatment modalities. Yamaguchi et al. [34] combined OK-432 with IL-2 into the pleural space in 16 patients with documented MPE from colorectal cancer. There was a cytologic response and decrease in effusion volume in 9 of $11(82 \%)$ patients treated with OK-432 alone and in all 5 patients treated with OK-432 plus IL-2. It is of particular interest that their immunologic analysis demonstrated that OK-432 plus IL-2 induced autologous tumor-reactive CD4+ Th1 killer lymphocytes which recognized tumor antigen presented with HLA class II. In a phase II study, Ikehara et al. [35] treated 15 patients with MPE with IP OK-432 followed by standard systemic che- motherapy with cisplatin and gemcitabine. Of the 15 patients, 1 achieved PR, 13 had stable disease, and 1 had progressive disease, with an overall response rate of $6.7 \%$. The median survival time was 13.5 months and the 1 -year survival rate was $60.0 \%$. Compared to historical controls, Ikehara et al. [35] reported superior survival with combined IP immunotherapy and systemic chemotherapy compared to standard chemotherapy.

Ren et al. [36] instilled staphylococcal super antigen (SSAg) into the pleural space of patients with stage IIIb lung cancer with poor performance status (ECOG PS $\geq 2$ ). Fourteen consecutive unselected patients received IP SSAg once or twice weekly until pleural effusions resolved. Eleven patients had a CR and 3 patients had a PR (CR was defined as complete resolution of MPE). In 12 patients, the response endured for $>90$ days, with a median time to recurrence of 5 months (range 3-23 months). The median survival of the 14 SSAg-treated cases and 13 consecutive talc-poudrage-treated patients with comparable pretreatment performance status was 7.9 and 2.0 months, respectively ( $p=0.0023$ ). Nine of 14 patients treated with SSAg survived $>6$ months, 4 patients survived $>9$ months, and 3 patients survived $>350$ days. One of the patients in the CR group has survived 36 months. None of the 13 talctreated patients survived $>6$ months [36]. These data seem to corroborate that nonspecific activation of the immune system can have significant effects not only on local control of MPE but also potentially on survival.

While many of these immunotherapy investigations indicate that this form of therapy may be a feasible option for MM or recurrent MPEs, as stated earlier, they are limited by their lack of randomization and appropriate control groups. Nevertheless, with the minimal toxicities associated with these therapies, more effort must be made to pursue larger randomized controlled trials to ascertain if these therapies should become realistic additions to the armamentarium of treatment modalities for pleural neoplasms. Other problems with IP cytokine delivery include: requirement of systemic leakage for large doses; need for repeated dosing; induction of pleurodesis fusing pleural surfaces and precluding additional dosing, and unreliable availability of recombinant proteins for use in clinical trials.

\section{IP Gene Therapy}

Approximately 20 years ago, advances in molecular genetics and gene transfer technology made possible the development of 'gene therapy' - the modification of the 


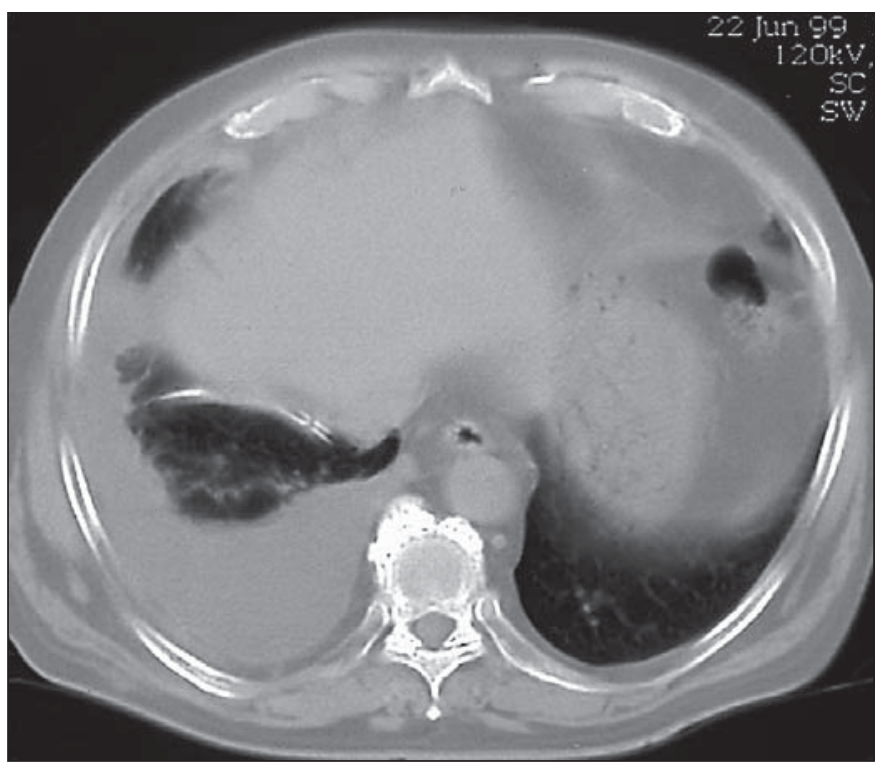

Fig. 1. Axial chest CT scan image from a patient with a right-sided MPM with an indwelling pleural catheter (PleurX; CareFusion, San Diego, Calif., USA) utilized for instillation of recombinant adenoviral vector into the pleural space for delivery of the therapeutic gene to mesothelioma cells lining the right pleural space. The presence of the catheter allows for safe, repeated access of the pleural space for cellular sampling to establish the presence and duration of intratumoral gene transfer, as well as assessment of IP cellular, humoral, and cytokine immune responses.

genetic makeup of cells for therapeutic purposes. Although the disorders originally proposed as targets for gene therapy were the inherited, recessive disorders in which transfer of a normal copy of a single defective gene could potentially alter the course of a disease (i.e. cystic fibrosis and alpha-1 antitrypsin disease), it soon became apparent that the range of target diseases could be extended to acquired disorders, such as inflammatory diseases and cancer. The concept of gene therapy now encompasses the treatment of any pathophysiologic state based upon the transfer of genetic material, including complementary DNA (cDNA), full-length genes, small interfering RNA (si-RNA), or oligonucleotides. This definition also includes approaches where genetically altered cells are introduced to alter the disease state.

Gene therapy involving the pleural space offers a number of potential advantages. The pleural space has a large surface area lined by a thin layer of mesothelial cells, the ideal configuration for efficent gene transfer. Liquids or cell suspensions injected into the pleural space would disseminate rapidly and uniformly within the hemithorax, facilitating transduction of a large surface area of mesothelium with the gene of interest. The patterns of fluid drainage from the pleural space through vascular and lymphatic channels would ensure rapid systemic uptake of any secreted proteins engendered by mesothelial transgene expression. In addition, access to the pleural space is relatively easy and safe (fig. 1). Unlike the peritoneal cavity, where adhesions and inflammation can cause severe complications, fusion of the pleural space is quite benign and in some instances (i.e. symptomatic MPE) may even be desirable.

\section{Goals for Gene Therapy of the Pleural Space}

Gene transfer to the pleural space could be employed in at least two possible scenarios. First, the cells of the pleural space could be used as factories to produce missing or defective gene products that would be secreted and then transferred into the systemic circulation. There are a number of diseases, such as hemophilia, $\alpha-1$ antitrypsin disease, lysosomal storage disorders, or diabetes, where regulated or unregulated secretion of difficult-to-produce protein products would be advantageous. Second, gene therapy could be utilized in the treatment of pleural malignancies, including primary pleural tumors (MM) and secondary metastatic tumors.

\section{Vectors Used in Pleural Gene Therapy}

The first requirement for successful gene therapy is efficient gene delivery, and a variety of viral and nonviral gene transfer vectors have been developed $[37,38]$. As summarized in table 1, each of these vectors has certain advantages with regard to DNA-carrying capacity, types of cells targeted, in vivo gene transfer efficiency, duration of expression, and induction of inflammation.

\section{Retroviruses}

The principal advantages of this vector derive from its availability to accomplish efficient gene transfer in vitro in a broad range of targeted cells, with the capacity to achieve integration into the host genome and long-term expression. However, the packaging capacity of the virion is limited and the vectors can achieve gene transfer only to dividing cells. Moreover, these vectors are labile in vivo since complement and other components can inactivate the virion. The requirements for cell proliferation and in vivo lability have severely limited the utility of these 
Table 1. Gene therapy vectors utilized for IP delivery

\begin{tabular}{|c|c|c|c|}
\hline Vector & Advantages & Disadvantages & Use in clinical trials in the pleura \\
\hline \multirow[t]{3}{*}{ Retrovirus } & $\begin{array}{l}\text { efficient entry into dividing } \\
\text { cells }\end{array}$ & $\begin{array}{l}\text { difficult to produce in sufficient } \\
\text { amount for use in human trials }\end{array}$ & $\begin{array}{l}\text { used ex vivo for transfection of allogeneic } \\
\text { tumor cells }\end{array}$ \\
\hline & viral genes absent & limited cassette insertion size & $\begin{array}{l}\text { no trials of direct IP instillation in } \\
\text { humans }\end{array}$ \\
\hline & $\begin{array}{l}\text { stable integration into the host } \\
\text { genome }\end{array}$ & insertional oncogenesis & \\
\hline \multirow[t]{3}{*}{ Adenovirus } & $\begin{array}{l}\text { efficient entry into dividing } \\
\text { and nondividing cells }\end{array}$ & viral genes must be in the vector & $\begin{array}{l}\text { most commonly used vector for IP gene } \\
\text { therapy trials in humans }\end{array}$ \\
\hline & high transgene expression & $\begin{array}{l}\text { induces immune responses that } \\
\text { can limit repeat dosing }\end{array}$ & $\begin{array}{l}\text { shown to transduce both IP tumor and } \\
\text { normal mesothelium }\end{array}$ \\
\hline & $\begin{array}{l}\text { no integration into the host } \\
\text { genome }\end{array}$ & & \\
\hline \multirow[t]{3}{*}{ AAV } & $\begin{array}{l}\text { chromosomal integration at a } \\
\text { specific site }\end{array}$ & small insert size for transgene & $\begin{array}{l}\text { primary use in animal models of somatic } \\
\text { mutations (i.e. hemophilia, A1AT Def) }\end{array}$ \\
\hline & $\begin{array}{l}\text { minimal immune response } \\
\text { elicited }\end{array}$ & $\begin{array}{l}\text { difficult to produce in sufficient } \\
\text { amount for use in human trials }\end{array}$ & $\begin{array}{l}\text { no trials of direct IP instillation in } \\
\text { humans }\end{array}$ \\
\hline & & variable transduction of tumors & \\
\hline \multirow[t]{2}{*}{ Liposomes } & $\begin{array}{l}\text { easy to produce in sufficient } \\
\text { amount for use in human } \\
\text { trials }\end{array}$ & inefficient entry into target cells & single human trial with E1A gene delivery \\
\hline & $\begin{array}{l}\text { minimal immune responses } \\
\text { that allow for repeat dosing }\end{array}$ & & $\begin{array}{l}\text { may be most beneficial for trials requiring } \\
\text { repeated administration of vector }\end{array}$ \\
\hline \multirow[t]{2}{*}{$\begin{array}{l}\text { Allogeneic } \\
\text { tumor cells }\end{array}$} & $\begin{array}{l}\text { homing to tumor cells in the } \\
\text { pleural space }\end{array}$ & $\begin{array}{l}\text { induces immune responses that } \\
\text { can limit repeat dosing }\end{array}$ & $\begin{array}{l}\text { single human trial with PA1-STK delivery } \\
\text { in MPM }\end{array}$ \\
\hline & $\begin{array}{l}\text { high transgene expression in } \\
\text { carrier cells }\end{array}$ & $\begin{array}{l}\text { use with HSVtk transgene } \\
\text { requires a strong bystander effect }\end{array}$ & $\begin{array}{l}\text { mesenchymal stem cells may be more } \\
\text { efficient vectors }\end{array}$ \\
\hline
\end{tabular}

agents in the context of direct in vivo delivery applications.

Retroviruses have been used to transduce mesothelial cells (or tumor cells) in culture for subsequent reinjection (see below) and this will likely be their most useful role in pleural gene therapy [39]. Successful use of retroviruses for in vivo transduction into the pleural and peritoneal space has been limited. Concentrated vector encoding a suicide gene has been reported to treat cancer cells in the peritoneal cavity [40]. Use in malignant pleural disease may be limited by the presence of chondroitin sulfate proteoglycans/glycosaminoglycans that appear to inhibit retroviral gene transfer [41].

\section{Adeno-Associated Virus}

Another viral vector that has generated significant interest is the adeno-associated virus (AAV), a defective parvovirus with a single-strand DNA genome and a na- ked protein coat [42]. AAV has not been associated with any known human disease state, suggesting a significant safety margin for this vector. In addition, after wild-type AAV entry into the host cell, there is a site-specific DNA integration step. It appears that recombinant vectors do not retain this integrative capacity but do seem to persist in an episomal state that allows for stable, long-term gene expression while potentially circumventing the safety concerns surrounding an integration event. To date, there have been no published reports of AAV-mediated gene therapy in human pleural diseases.

\section{Adenoviruses}

The most widely used vector system in human clinical trials of IP gene therapy has been recombinant, replication-incompetent adenovirus. Recombinant adenoviral vectors have deletions of crucial viral genes needed for replication and are produced by packaging cell lines that 
provide these functions in trans [43]. The deleted gene regions can then be replaced with expression cassettes containing the desired gene under the control of general or tumor-specific promoters. This vector system offers a number of advantages such as high-efficiency transduction of target cells (including nondividing cells) and high expression levels of the delivered transgene [44]. The two primary disadvantages of adenoviruses in traditional gene therapy are that they result in only transient gene expression and that, when employed for direct in vivo applications, the virions elicit a prominent local and systemic inflammatory response [45]. However, transitory gene expression and induction of intratumoral inflammation leading to a more 'immunostimulatory' environment may be a distinct advantage for cancer gene therapy.

Mesothelial and mesothelioma cells (as well as other tumor cell lines) in culture are quite readily transduced by adenoviral vectors. More importantly, these vectors have been injected into the pleural and peritoneal spaces in animal models with demonstration of high-level target cell transduction [46-48]. Despite reports of soluble factors in pleural fluid of MPEs that inhibit adenoviral gene transfer [49], our group has injected adenoviral vectors into the pleural space of patients with MM and confirmed intratumoral gene transfer of tumor by detection of transgene DNA, RNA, and protein at 3 days after vector instillation (see below) [50].

\section{Nonviral Vectors}

A variety of nonviral vectors have also been developed for in vivo and in vitro gene delivery, with liposomes being the most common nonviral vector utilized in animal models and human clinical trials. Liposomes are artificial lipid bilayers designed to translocate drugs or nucleic acids into the cell cytosol via a cell-membrane fusion event or endocytosis. The basis of transduction is interaction of a DNA/lipid complex with target cell membranes to allow translocation to cell cytosol. For the most part, liposomal/DNA complexes are less efficient than the various viral vectors described above, and they do not result in prolonged transgene expression. Nonetheless, their design offers certain potential advantages, including simplicity of construction, enhanced DNA packaging capacity, lessened safety concerns, and the potential for targeted genedelivery, that warrant theirfurther development [51].

There have been a number of studies utilizing liposomes for intraperitoneal gene transfer, primarily for treatment of cancer. These studies have shown successful gene transfer into tumor cells along with varying degrees of tumor inhibition. Pleural gene transfer to treat a model of metastatic pleural disease using liposomes has also been reported [52]. Hortobagyi et al. [53] at the M.D. Anderson Cancer Center in Houston, Tex., USA, conducted a phase I trial examining the weekly injection of cationic liposomes containing the adenoviral E1A transgene (DCC-E1A) into the thoracic or peritoneal cavities of 18 patients with advanced cancer of the breast $(n=6)$ or ovary $(n=12)$. E1A gene expression in tumor cells was detected by immunohistochemical staining and reverse transcriptase-polymerase chain reaction (RT-PCR). E1A gene expression was accompanied by HER-2/neu downregulation, increased tumor cell apoptosis, and reduced proliferation. The most common treatment-related toxicities were fever, nausea, vomiting, and/or discomfort at the injection sites [53].

In the future, the most likely use for pleural gene therapy will be in the treatment of malignant diseases including $\mathrm{MM}$ and metastatic pleural disease. Pleural malignancies have several characteristics that make them attractive targets for gene therapy, including: (1) absence of standard, effective therapy; (2) accessibility in the pleural space for biopsy, vector delivery, and analysis of treatment effects, and (3) susceptibility to therapeutic strategies requiring only transient gene expression. $\mathrm{MM}$ is an especially attractive target since local extension of disease, rather than distant metastases, is responsible for much of its morbidity and mortality. Accordingly, a large number of animal studies and some clinical trials have been performed using gene therapy approaches [1].

Several different cancer gene therapy approaches are currently being explored for malignant pleural tumors, including use of so-called 'suicide genes', delivery of tumor suppressor genes, and transfer of immunomodulatory genes (table 2).

\section{Suicide Gene Therapy}

One prominent approach in cancer gene therapeutics is so-called 'suicide' gene therapy wherein a neoplasm is transduced with a cDNA encoding for an enzyme rendering tumor cells sensitive to a 'benign' agent by converting the 'prodrug' to a toxic metabolite. The enzyme used most commonly in human clinical trials and in animal models is the herpes simplex virus-1 thymidine kinase (HSVtk) gene, which when incorporated into malignant cells renders them sensitive to the nucleoside analogs ganciclovir (GCV) and valacyclovir and induces cell killing [54]. Therapeutic efficacy is enhanced by the finding that transgene expression in every cell is not required for complete tumor regression. This so-called 'bystander' ef- 
Table 2. IP gene therapy trials for pleural malignancy

\begin{tabular}{|c|c|c|c|c|c|c|}
\hline Study (year) Phase & Histology & $\begin{array}{l}\text { Total evaluable, } \\
\mathrm{n}\end{array}$ & Agent & Delivery & Best clinical response (\%) & $\begin{array}{l}\text { Additional outcome } \\
\text { measures }\end{array}$ \\
\hline \multicolumn{7}{|c|}{ Immunogene therapy } \\
\hline $\begin{array}{l}\text { Sterman et I } \\
\text { al. [50] } \\
(1998)\end{array}$ & MPM & 21 & Ad.HSVtk/GCV & $\begin{array}{l}\text { IP }- \text { single } \\
\text { dose; GCV } \times 14 \text { days }\end{array}$ & $\begin{array}{l}\text { gene transfer confirmed in } 11 \\
\text { of } 20 \text { evaluable patients in a } \\
\text { dose-related fashion }\end{array}$ & $\begin{array}{l}\text { strong anti-adenoviral } \\
\text { immune responses } \\
\text { generated, including high } \\
\text { titers of neutralizing } \\
\text { antibody and T-cell } \\
\text { proliferative responses }\end{array}$ \\
\hline $\begin{array}{l}\text { Sterman et I } \\
\text { al. [67] } \\
(2000)\end{array}$ & MPM & 8 & $\begin{array}{l}\text { Ad.HSVtk/GCV } \\
\text { + corticosteroids }\end{array}$ & $\begin{array}{l}\mathrm{IP}-\text { single } \\
\text { dose; } \mathrm{GCV} \times 14 \text { days }\end{array}$ & $\begin{array}{l}2 \text { long-term survivors with } \\
\text { stable disease for } 6 \text { years } \\
\text { posttreatment }\end{array}$ & $\begin{array}{l}\text { safety and toxicity without } \\
\text { difference from initial } \\
\text { clinical trial }\end{array}$ \\
\hline $\begin{array}{l}\text { Hortobagyi I } \\
\text { et al. [53] } \\
(2001)\end{array}$ & $\begin{array}{l}\text { MPE } \\
\text { (breast) } \\
\text { (ovarian) }\end{array}$ & $\begin{array}{l}6 \text { (breast); } \\
12 \text { (ovary) }\end{array}$ & DCC-E1A & $\begin{array}{l}\text { IP }(\mathrm{n}=6) \text {; } \\
\text { intraperitoneal }(\mathrm{n}=12) \text {; } \\
\text { weekly injection }\end{array}$ & $\begin{array}{l}\text { E1A gene expression in } \\
\text { tumor cells detected by IHC } \\
\text { and RT-PCR }\end{array}$ & $\begin{array}{l}\text { E1A gene expression was } \\
\text { accompanied by HER-2/neu } \\
\text { downregulation, increased } \\
\text { tumor cell apoptosis, and } \\
\text { reduced proliferation }\end{array}$ \\
\hline $\begin{array}{l}\text { Sterman et I } \\
\text { al. [74] } \\
(2007)\end{array}$ & $\begin{array}{l}\text { MPM } \\
\text { MPE }\end{array}$ & $\begin{array}{l}7 \text { (MPM); } \\
3 \text { (MPE) }\end{array}$ & Ad.IFN- $\beta$ & $\begin{array}{l}\text { IP - single } \\
\text { dose }\end{array}$ & $\begin{array}{l}1(10 \%) \text { with CR, } 2(20 \%) \\
\text { with PR, } 4(40 \%) \text { with SD }\end{array}$ & $\begin{array}{l}\text { successful gene transfer, } \\
\text { induction of humoral/innate } \\
\text { immune response }\end{array}$ \\
\hline $\begin{array}{l}\text { Dong et al. I } \\
{[80]} \\
(2008)\end{array}$ & $\begin{array}{l}\text { MM } \\
\text { MPE }\end{array}$ & $\begin{array}{l}27 \text { (treatment); } \\
21 \text { (control) }\end{array}$ & $\begin{array}{l}\text { Ad.wt-p53 } \pm \\
\text { IP cisplatin }\end{array}$ & $\begin{array}{l}\text { IP/ } \\
\text { intraperitoneal - } \\
\text { weekly } \times 4\end{array}$ & $\begin{array}{l}\text { total effective rates for the } \\
\text { treatment group ( } 63.0 \%) \text { and } \\
\text { for the control group }(42.9 \%)\end{array}$ & safety and toxicity \\
\hline $\begin{array}{l}\text { Zhao et al. I } \\
{[81]} \\
(2009)\end{array}$ & $\begin{array}{l}\text { stage IVA } \\
\text { NSCLC } \\
\text { (MPE) }\end{array}$ & $\begin{array}{l}17 \text { (combined); } \\
18 \text { (control) }\end{array}$ & $\begin{array}{l}\text { Ad.wt-p53 } \pm \\
\text { IP cisplatin }\end{array}$ & IP - weekly $\times 4$ & $\begin{array}{l}\text { total effective rates in the } \\
\text { combined group } 82.35 \% \text { and } \\
\text { in the single-agent group } \\
50.00 \%\end{array}$ & safety and toxicity \\
\hline $\begin{array}{l}\text { Sterman et I } \\
\text { al. [75] } \\
(2010)\end{array}$ & $\begin{array}{l}\text { MPM } \\
\text { MPE }\end{array}$ & $\begin{array}{l}10 \text { (MPM); } \\
7 \text { (MPE) }\end{array}$ & Ad.IFN- $\beta$ & IP - two doses & $\begin{array}{l}3(18 \%) \text { with PR/MR, } 11 \\
(61 \%) \text { with SD }\end{array}$ & $\begin{array}{l}\text { successful gene transfer with } \\
\text { first dose but not second, } \\
\text { induction of humoral } \\
\text { immune response }\end{array}$ \\
\hline $\begin{array}{l}\text { Sterman et I } \\
\text { al. [76] } \\
(2011)\end{array}$ & MPM & 9 & Ad.IFN- $\alpha 2 b$ & IP - two doses & 2 (22\%) PR, 4 (44\%) with SD & $\begin{array}{l}\text { Ad.IFN- } \alpha \text { induced much } \\
\text { higher levels of gene transfer } \\
\text { than Ad.IFN- } \beta \text {; induction of } \\
\text { humoral/innate immune } \\
\text { response }\end{array}$ \\
\hline $\begin{array}{l}\text { Schwarzen- I } \\
\text { berger et al. } \\
\text { [61] } \\
(2011)\end{array}$ & MPM & 15 & $\begin{array}{l}\text { PA1-STK } \\
\text { cells/GCV }\end{array}$ & $\begin{array}{l}\text { multiple IP } \\
\text { infusions (every } 4 \text { weeks } \\
\times 3 \text { ) followed by } 7 \text { days } \\
\text { of intravenous GCV }\end{array}$ & $\begin{array}{l}\mathrm{CR}(\mathrm{n}=0), \mathrm{PR}(\mathrm{n}=0) \text {, and } \\
\text { stable disease }(\mathrm{n}=9) \text { and } \\
(\mathrm{n}=3) \text { at } 3 \text { and } 6 \text { months, } \\
\text { respectively. }\end{array}$ & $\begin{array}{l}\text { median overall survival } \\
\text { from the time of treatment } \\
\text { initiation: } 7.7 \text { months }\end{array}$ \\
\hline $\begin{array}{l}\text { Haas and IIA } \\
\text { Sterman } \\
(2012)\end{array}$ & MPM & ongoing & Ad.IFN- $\alpha 2 b$ & $\begin{array}{l}\text { IP - two doses } \\
\text { with: (i) pemetrexed + } \\
\text { platin; (ii) gemcitabine } \\
\pm \text { platin }\end{array}$ & ongoing & $\begin{array}{l}\text { gene transfer, immune } \\
\text { response, safety and toxicity }\end{array}$ \\
\hline
\end{tabular}

Ad = Adenovirus; DCC-E1A = liposomal E1A gene conjugate; IHC = immunohistochemical staining; Ad.wt-p53 = adenovirus wild-type p53 gene construct; $\mathrm{MR}=$ mixed response; $\mathrm{SD}=$ stable disease.

fect is complex and appears to involve passage of toxic GCV metabolites from transduced to nontransduced cells via gap junctions or apoptotic vesicles $[55,56]$ and/ or induction of anti-tumor immune responses capable of killing tumor cells not expressing the HSVtk transgene
[57]. The transfer of HSVtk DNA to target tumor cells has been accomplished in a variety of ways including the use of cellular delivery systems, liposomes, and viral vectors.

One approach was to transduce tumor cells ex vivo with HSVtk and inject them into the peritoneal or pleural 
cavity. Treatment with GCV was shown to induce death of the transduced cells accompanied by a powerful bystander effect which was amplified by release of immunostimulatory cytokines that led to killing of nontransduced cells [58] This approach has been directly tested in mouse models of intraperitoneal MM in which injection of an HSVtk-transduced ovarian cancer cell line (PA-1) into mice with established MM followed by GCV treatment led to a marked increase in survival [59]. Interestingly, the LSU investigators have also demonstrated that PA1-STK cells home to MM deposits in patients after IP instillation [60].

Based on these studies, a cell-transfer trial was conducted by Schwarzenberger et al. [61] at the Louisiana State University (LSU) Medical Center in New Orleans. The study was a phase I clinical trial involving direct IP infusion of escalating doses of HSVtk suicide gene-modified PA1STK cells in 15 patients with MM followed by 7 days of intravenous GCV. The first two cohorts received a single IP dose via an indwelling pleural catheter; cohorts 3-5 received three weekly doses. The treatment was well tolerated without any grade 3 or 4 toxicity. Significant inductions of both Th1 and Th2 cytokines up to 20fold over baseline were observed. No significant differences were seen between serum and pleura cytokine profiles, with the exception of IL-10, which was consistently elevated in the pleural fluid specimens. No objective radiographic responses were observed in any of the treated patients [61].

The most effective and most carefully studied vector for suicide gene delivery, however, has been adenovirus. Initial experiments demonstrated that replication-deficient adenoviral HSVtk vectors (Ad.HSVtk) efficiently transduced mesothelioma cells both in tissue culture and in animal models and facilitated HSV $t k$-mediated killing of human mesothelioma cells in the presence of low concentrations of GCV $[62,63]$. Subsequently, Ad.HSVtk/ GCV gene transfer was used successfully to treat established, intraperitoneal human MM tumors and lung cancers in immunodeficient mice $[64,65]$ and in rat models of MM [48, 65].

Based on success in animal models, Sterman et al. [50] conducted a phase I clinical trial of a replication-incompetent adenoviral vector encoding HSVtk (Ad.HSVtk) delivered IP to 21 patients with MM [50, 66]. After vector instillation, patients were treated with 2 weeks of systemic GCV. Dose-limiting toxicity was not reached, side effects were minimal, and gene transfer was confirmed in 11 of 20 evaluable patients in a dose-related fashion with clearly detectable gene transfer (evidenced by immuno- staining) at tumor surfaces and up to $30-50$ cell layers deep. Strong anti-adenoviral immune responses, including high titers of neutralizing antibody and proliferative T-cell responses, were generated [50]. A second trial was reported investigating the use of systemic corticosteroids to mitigate anti-vector immune responses. A similar group of patients as previously described was treated with vector plus high-dose corticosteroids for 3 days. In comparison to patients treated with the same dose of IP Ad.tk, corticosteroid-treated patients demonstrated decreased localized and systemic inflammatory responses and showed a trend towards increased intratumoral gene transfer. Intravenous methylprednisilone failed to inhibit the generation of anti-Ad antibodies or Ad-induced peripheral blood mononuclear cell activation [67]. Although limited by the small numbers of patients studied, the data indicated that administration of systemic steroids was safe and may limit acute clinical toxicity; however, these agents are not likely to significantly inhibit cellular and humoral responses to adenoviral vectors. Despite the fact that these were phase I trials, some clinical responses were seen; 2 patients remained tumor free 3 years after treatment and partial tumor regression was observed in a number of the patients receiving the higher doses of vector.

An additional 8 patients were treated with a slightly modified Ad.tk virus (E1/E4-deleted) that had a lower incidence of recombination to form wild-type virus. Of the 8 patients treated in this second phase I trial, there were 2 long-term survivors, both of whom were treated at the higher dose level of $5.0 \times 10^{13}$ particles of Ad.HSVtk, and both had clinically and radiographically stable disease without other anti-tumor therapy for 6 years after treatment. There was no significant difference in side effect profile compared to the previous trial [67].

This clinical data showing limited toxicity and detectable gene transfer, as well as our anecdotal tumor responses, suggest the Ad.tk/GCV approach has potential for the treatment of MM as well as other pleural malignancies. Using the current strategy, therapeutic efficacy could primarily be expected in patients with a relatively small tumor burden. An alternative treatment schema might involve administration of IP Ad.tk as neo-adjuvant therapy followed by surgical 'debulking' to minimize the tumor burden. Another method of improving intratumoral gene transfer would be repeated administration of vector and GCV, the use of adenoviral vectors capable of selective replication in mesothelioma cells, or combination therapy of IP Ad.tk gene transfer with standard chemotherapy. 
Cytokine Gene Therapy

There has been significant interest at many centers in the delivery of genes encoding cytokines to the pleural space of patients with MM. The rationale for this approach is that expression of cytokine genes by tumor cells generates a high level of intratumoral cytokines in an autocrine and paracrine fashion, inducing powerful local cytokine effects while minimizing systemic toxicity. Prolonged local cytokine expression can induce direct tumor cell apoptosis and inhibit tumor angiogenesis but, perhaps most importantly, induces anti-tumor immune responses. Cytokine gene delivery activates tumor-infiltrating dendritic cells (DCs) to express MHC-tumor antigen complexes in conjunction with co-stimulatory molecules. These activated DCs can then migrate to regional lymph nodes where they stimulate proliferation of tumor specific CD8 and CD4 lymphocytes, inducing anti-tumor cytotoxicity at distant sites of tumor. In addition, some proinflammatory cytokines such as IL-2 and IL-12 have the capability of direct intratumoral activation of CD8+ tumor-infiltrating lymphocytes, overcoming tolerance signals to produce tumor-specific cytotoxic $\mathrm{T}$ lymphocytes. Increased intratumoral IL-2 and IL-12 may also activate NK cells $[68,69]$. This approach has obvious appeal for metastatic pleural disease where local treatment would offer the possibility of systemic immune responses.

The first human clinical trial of direct intratumoral delivery of cytokine genes in malignant pleural mesothelioma (MPM) was conducted by investigators at Queen Elizabeth II Hospital in Perth, Australia, using a recombinant vaccinia virus (VV) expressing the human IL-2 gene. A vaccinia vector was chosen because of its large genome, proven safety in human vaccines, and availability of anti-VV antibodies for evaluation of vector-induced immune responses. In addition, insertion of the IL-2 gene into the TK region of the VV rendered it partially replication restricted, allowing for increased expression in tumor cells. The VV-IL-2 vector was serially injected into palpable chest wall lesions of 6 patients with advanced MM. Toxicities were minimal, and there was no clinical or serological evidence of spread of VV to patient contacts. VV-IL-2 mRNA was detected by RT-PCR in serial tumor biopsies for up to 6 days after injection but declined to low levels by day 8 . Unfortunately, no significant tumor regression was seen in any of the patients, and only modest intratumoral T-cell infiltration was detected on tumor biopsies [70]. Nonetheless, the prolonged nature of IL-2 gene expression in this trial was remarkable considering the fact that significant serum titers of anti-VV neutralizing antibodies were generated in all patients.

As previously discussed, several clinical trials in the early 1990s demonstrated evidence of the safety and anecdotal efficacy of IP administration of recombinant IFN proteins in patients with early-stage MPM [28, 29, 71, 72]. Progress with this approach, however, was hampered due to problems such as drug availability, short in vivo halflife and lack of sustained tissue levels of the recombinant proteins, toxic effects of systemic administration, and limitation of demonstrable clinical effects to early-stage patients $[28,29]$.

IP IFN- $\beta$ administration for metastatic pleural effusions showed a reasonable safety profile, but with minimal clinical benefit, likely due to several of the same issues that limited application of recombinant interferons in mesothelioma. To overcome these hurdles, investigators at the University of Pennsylvania Medical Center conducted preclinical studies of IFN- $\beta$ gene transfer in syngeneic murine models of MM [73].

The success of these in vivo experiments led in 2007 to the publication of the first human trial of IP interferon gene therapy for MM and MPE [74]. The study evaluated the safety and feasibility of a single-dose IP IFN- $\beta$ gene transfer using an adenoviral vector (Ad.IFN- $\beta$ ) in patients with MPM and metastatic pleural effusions. Ad. IFN- $\beta$ was administered via an indwelling pleural catheter in escalating doses in two cohorts of patients - MPM (7 patients) and MPE (3 patients) (fig. 1). Subjects were evaluated for toxicity, gene transfer, immune responses, and anti-tumor responses via 18-fluorodeoxyglucose (FDG)-positron emission tomography (PET) scans and chest computed tomography (CT) scans. IP Ad.IFN- $\beta$ was generally well tolerated, with transient lymphopenia as the most common side effect. Other side effects included hypoxia and liver function abnormalities. Gene transfer was documented in 7 of the 10 patients by demonstration of IFN- $\beta$ mRNA or protein expression in pleural fluid. Anti-tumor immune responses were demonstrated in 7 of the 10 patients and included detection of cytotoxic T cells, activation of circulating NK cells, and humoral responses to known tumor-associated antigens as well as to allogenic mesothelioma homogenates. Four of 10 patients showed meaningful clinical responses defined as disease stability and/or regression on PET and CT scans at day 60 after vector instillation [74].

This study demonstrated that administration of IP Ad.IFN- $\beta$ was feasible and well tolerated, and resulted in successful gene transfer as evidenced by the production of IFN- $\beta$ measured on ELISA of pleural fluid. Lastly, the 
study also demonstrated that a single IP dose of IFN- $\beta$ vector was able to induce measurable anti-tumor immune responses in most patients as well as anecdotal clinical responses in a heavily pretreated patient population [74].

Encouraged by the results of a single-dose IP IFN- $\beta$ gene transfer, a second phase I trial wsa conducted at the University of Pennsylvania Medical Center to determine whether two doses of Ad.IFN- $\beta$ vector would be superior to a single dose [75]. Ten patients with MPM and 7 with MPE (underlying primary malignancies: 3 lung cancer, 2 ovarian cancer, and 2 breast cancer), received two doses of Ad.IFN- $\beta$ through an indwelling pleural catheter. Because of potential safety concerns, the trial used a dose interval of 14 days initially for 13 patients. After demonstrating no additional toxicity, the remaining 4 patients were treated with a 7-day dosing interval. Repeated doses were generally well tolerated. The most common adverse events were lymphopenia, hypoalbuminemia, hypotension, anemia, hypocalcemia, and mild cytokine release syndrome (CRS) characterized by fever, rigors/chills, nausea, and tachycardia. One patient developed pericardial tamponade successfully treated by therapeutic pericardiocentesis; pericardial fluid analysis did not reveal malignant cells or IFN- $\beta$ and was negative on for adenoviral vector [75].

In this repeat dose gene transfer study, high levels of IFN- $\beta$ were detected in pleural fluid after the first dose; however, absent IP IFN- $\beta$ expression after the second dose correlated with the rapid induction of neutralizing Ad antibodies (Nabs). Antibody responses against tumor antigens were induced in most patients. At 2-month follow-up imaging, $1 \mathrm{MM}$ patient had a PR, 2 had stable disease, and 9 had progressive disease. On PET scanning, 2 patients had mixed responses and 11 had stable disease. There were 7 patients with survival times longer than 18 months. Overall, repeated IP instillation of Ad.IFN- $\beta$ vector was safe and induced immune responses and some evidence of clinical responses. However, rapid development of Nabs prevented effective gene transfer after the second dose, even with a dose interval as short as 7 days [75].

Based on these results, investigators at the University of Pennsylvania Medical Center designed a new phase I trial to evaluate a shortened dosing interval by administering a second dose of IP Ad-IFN vector 3 days after the first dose, prior to the expected peak of Nabs production. For this trial, the investigators at Penn utilized a recombinant, replication-incompetent adenovirus vector expressing the human interferon- $\alpha 2 b$ gene (Ad.IFN- $\alpha 2 b$ ) obtained from Schering-Plough/Merck (SCH721015), which had a nearly identical vector backbone [76].
Ad.IFN- $\alpha 2 b$ was instilled IP on study days 1 and 4 via a tunneled pleural catheter. The starting vector dose was $1 \times 10^{12}$ viral particles of Ad.hIFN- $\alpha 2 \mathrm{~b}$, but this dose was reduced to $3 \times 10^{11}$ after the first 3 patients developed significant CRS symptoms after the first dose of IP vector. Subjects were assessed for anti-tumor responses approximately 60 days after the initial treatment using CT and PET scans. Pleural fluid and serum IFN- $\alpha 2 b$ levels, mesothelin-related protein (SMRP) levels, and Nabs were measured using standard techniques. In general, Ad.IFN- $\alpha 2 b$ vector instillation was well tolerated, although most patients developed some CRS symptoms, typically after the initial dose. High and sustained serum IFN- $\alpha$ levels were sometimes associated with protracted 'flu-like symptoms' lasting 7-10 days. Pleural catheterrelated infections occurred in 2 patients and both were treated successfully with antibiotics [76].

Successful gene transfer and high IFN- $\alpha$ levels in pleural fluid were demonstrated even in patients who received a lower dose of vector. Furthermore, there was evidence that the second Ad.IFN- $\alpha 2 \mathrm{~b}$ dose resulted in successful gene transfer, unlike prior trials with Ad.IFN- $\beta$. All patients had markedly increased anti-Ad Nab titers (Nabs) 1 week after Ad vector instillation; however, low levels of Nabs were measured at the time of the second vector dose (day 4). There were encouraging immunologic responses such as new or increased intensity bands on immunoblots containing extracts of mesothelioma cell lines in 7 of 8 patients and upregulation of the activation marker CD69 on circulating NK cells [76].

At the time of first radiographic assessment (60 days), 3 subjects had progressive disease, 4 had stable disease, and 2 had PR using modified RECIST criteria. Two patients had sufficient improvement that they were subsequently able to undergo successful radical pleurectomy (RP), with no signs of recurrence 12 and 24 months postoperatively. One patient, who had been previously treated with RP and chemotherapy, had an impressive radiographic and metabolic tumor response in that many of the pleural-based malignant foci had regressed on PET/ CT by 2 months after vector instillations (fig. 2). On 6-month follow-up PET/CT, post-Ad.IFN- $\alpha 2 b$, many lesions had completely resolved, all at sites distant from vector instillation [76]. The most important outcome of the study was the demonstration of lower levels of Nabs at the shortened dosing interval with prolonged IP expression of the interferon transgene. The combination of a better dosing strategy as above as well as the higher potency and sustained levels of IFN- $\alpha$ may result in better anti-tumor responses in future clinical trials. 

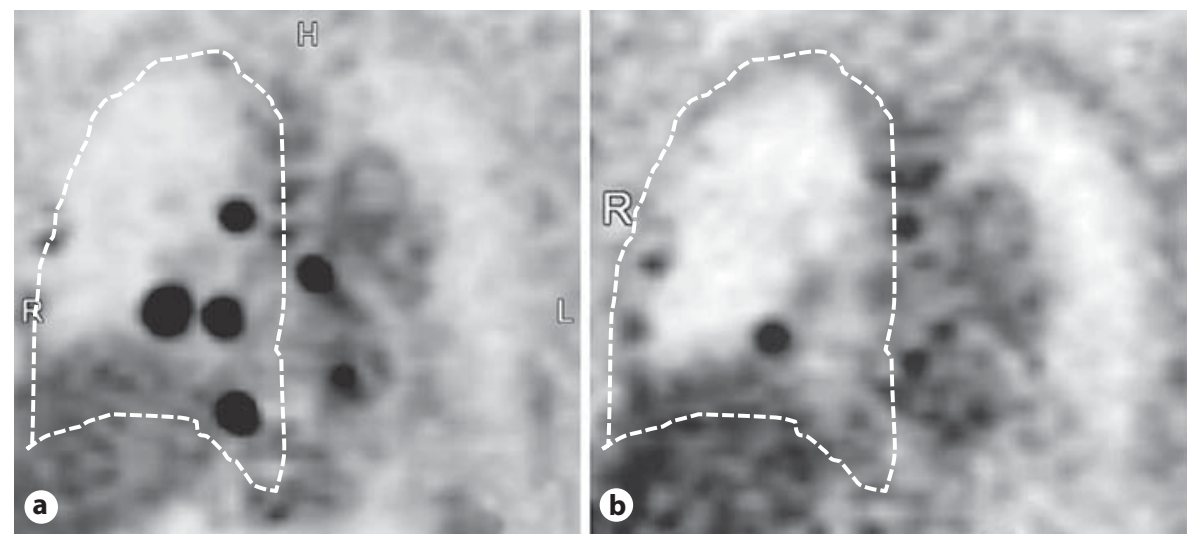

Fig. 2. Coronal reformatted 18-FDG PET scans before (a) and 2 months after (b) two doses of Ad.IFN- $\alpha 2$ b via a surgically implanted right pleural catheter in a patient with progressive mesothelioma status after prior right RP, intraoperative photodynamic therapy, and adjuvant pemetrexed-based combination chemo- therapy. b The follow-up PET scan at 2 months showed a dramatic decrease in hypermetabolic foci in the right hemithorax, as well as in the right hilar and mediastinal nodes. A repeat PET CT scan at 6 months showed a near CR (anatomic and metabolic) in the right hemithorax and mediastinum (data not shown).
Interferon gene therapy trials have mostly documented safety, successful gene transfer and induction of antitumor humoral and cellular immune responses but have shown only limited efficacy. Given the complex nature of the pathogenesis of many malignancies, the future may lie in combination gene therapy approaches. Use of oncolytic viruses and interferon gene transfer, for example, could improve outcomes by facilitating greater expression of cytokine genes within target tumors [38]. Use of other immunostimulatory molecules such as other cytokines or even tumor vaccines could offer promising outcomes and perhaps improve each other's efficacy [77].

Multimodality cancer treatment - i.e. surgical debulking, chemotherapy, and/or radiotherapy - in conjunction with interferon gene transfer may provide improved long-term outcomes in MM and other pleural malignancies. Based on promising preclinical data, the group at Penn has initiated a phase IIa clinical trial of repeateddose IP Ad.IFN-a in combination with standard chemotherapy for patients with MPM. In addition, a neoadjuvant surgery trial involving vector administration to patients with MPM followed by maximal cytoreduction and adjuvant chemotherapy is being planned. [78]

\section{IP Delivery of Tumor Suppressor Genes}

One of the primary approaches to cancer gene therapy research over the past decade has been mutation compensation - the replacement of absent or mutated tumor sup- pressor genes responsible, in part, for the malignant phenotype of the cancer cell. Intratumoral delivery of the wild-type p53 (wt-p53) gene, for example, has been the most frequent method used in human gene therapy trials for lung cancer and other solid tumors, as mutations in the p53 tumor suppressor gene account for the majority of genetic abnormalities in solid tumors. Most MM, however, contain wt-p53 and a normal copy of the cell cycle regulator retinoblastoma (pRB).

Despite the fact that most mesotheliomas have wt-p53, the function of p53 in mesothelioma cells may be abnormal secondary to binding of $\mathrm{p} 53$ by inhibitor proteins such as $\mathrm{mdm} 2$ and SV40 large T antigen. Therefore, there is a rationale for gene therapy of mesothelioma via overexpression of wt-p53 within the tumor cell. Giuliano et al. [79] in Chieti, Italy, performed a series of experiments in which they transfected human mesothelioma cells with a replication-deficient adenoviral vector carrying the wt-p53 gene. They demonstrated greater than $80 \%$ inhibition of tumor cell growth in vitro with documentation of induction of apoptosis in the dying tumor cells. In addition, Giuliano et al. [79] showed that ex vivo transfer of the wt-p53 gene to mesothelioma cells inhibited the growth of tumor implants in nude mice. In immunodeficient mice with established human mesothelioma xenografts, intratumoral injection of the wt-p53 gene inhibited tumor growth and prolonged survival. It is reasonable, therefore, to initiate human clinical trials of IP Ad.wt-p53 gene therapy in mesothelioma akin to those previously conducted in lung cancer, head and neck cancer, and metastatic colon cancer. 
In fact, IP p53 gene therapy clinical trials have been conducted in China for the treatment of malignant effusions secondary to mesothelioma and pleural metastases $[80,81]$. Recombinant adenoviral vectors carrying the wtp53 gene have been approved by the Chinese government for intratumoral injection in head and neck cancer (marketed as 'Gendicine'), and they have been utilized clinically with intratumoral injection in lung cancer as well as in the pleural space in clinical trials.

Dong et al. [80] evaluated the efficacy of recombinant adenovirus p53 agent (rAd-p53) injection combined with IP cisplatin for the treatment of malignant pleural or peritoneal effusion. After thoracentesis or paracentesis, patients in the treatment group $(n=27)$ received intracavitary administration of rAd-p53 once a week for 4 weeks. At $48 \mathrm{~h}$ after each rAd-p53 injection, patients were given cisplatin intracavitarily. The control group $(\mathrm{n}=21)$ received the same intracavitary cisplatin as the treatment group but without rAd-p53 therapy. Efficacy was evaluated by clinical observations, CT, tumor markers, Karnofsky score, and short-term follow-up. The total effective rates (evaluated by control of the malignant effusion) for the treatment group (63.0\%) were significantly higher than for the control group (42.9\%) [80].

Zhao et al. [81] also evaluated the clinical efficacy and toxicity of rAd-p53 combined with cisplatin in treatment of MPE related to metastatic lung cancer. A total of 35 patients with MPE secondary to bronchogenic carcinoma were randomly divided into a combined group (IP cisplatin/rAd-p53) ( $\mathrm{n}=17)$ and a single-agent group (IP cisplatin) $(\mathrm{n}=18)$. Both groups were administered cisplatin \pm rAd-p53 intracavitarily once a week for 4 weeks. The total effective rates (based on control of MPE) in the combined group and the single-agent group were 82.35 and $50.00 \%$ $(p<0.05)$, respectively. The toxicities in the two groups included fever, nausea/vomiting, and leukopenia. The principal toxicity in the combined group was self-limited fever $(\mathrm{p}<0.05)$, which spontaneously resolved $36 \mathrm{~h}$ after vector administration [81].

Both studies noted superior control of pleural (and peritoneal) effusion in patients who received the Ad.p53based combination therapy, but both studies were limited by the lack of data on tumor response rates or survival $[80,81]$. Therefore, it is possible that this approach may have only been useful in achieving pleurodesis as a result of an inflammatory reaction to repeated IP administration of the adenoviral vector, without any significant effect of wt-p53 gene expression on the primary tumor.

\section{Conclusion}

Pleural malignancies, both primary and metastatic, are excellent targets for novel IP therapeutic approaches as they are invariably fatal with few treatment options. In addition, the ease of repeat access of the pleural space for thoracoscopic examination and/or pleural fluid sampling facilitates research into the effects of novel therapies, as it is possible to provide nearly real-time assessment of antitumor effects, induction of immune responses, and IP complications such as infection. IP chemotherapy has proven to be of minimal benefit on its own in pleural malignancies but may be beneficial in combination with maximal tumor debulking, as well as with hyperthermia. Delivery of immunotherapies into the pleural space in patients with pleural malignancy may be most effective in those patients with early-stage malignancy, such as mesotheliomas limited to the pleural surface. In addition, they may prove superior to standard pleurodesis methods in control of effusion and prolongation of survival, but larger, randomized studies are needed to answer these questions more definitively. Gene therapy is a promising treatment for a variety of human diseases - particularly for pleural malignancies - but has not been incorporated into routine clinical use because sufficient delivery of therapeutic genes to effectively kill large numbers of cancer cells has proved challenging. Clinical trials of IP wtp53 gene delivery have proven beneficial in controlling pleural effusions in patients with malignant pleuritis secondary to lung cancer but have not demonstrated clear evidence of tumor responses. Recent and ongoing immunogene therapy and clinical trials using recombinant adenovirus carrying genes encoding human for interferons have demonstrated the ability to induce humoral and cellular anti-tumor immune responses and some measurable tumor reductions in patients with heavily pretreated pleural malignancies. Mesothelioma is an ideal target for immunogene therapy because no treatment (surgery, chemotherapy, and/or radiation) has been able to effectively treat the disease and because mesothelioma tends to remain localized until the late stages of the disease. Even immunogene therapy is limited in its ability to destroy large tumors, which is why researchers are investigating combination approaches that combine traditional therapies such as debulking surgery and chemotherapy with IP genetic immunotherapy. 


\section{References}

$\checkmark 1$ Sterman DH, Albelda SM: Advances in the diagnosis, evaluation and management of malignant pleural mesothelioma. Respirology 2005;10:266-283.

$\checkmark 2$ Bone G: Postoperative empyema and survival in lung cancer. Br Med J 1973;2:178.

$\checkmark 3$ Ruckdeschel JC, Codish SD, Stranahan A, et al: Postoperative empyema improves survival in lung cancer: documentation and analysis of a natural experiment. N Engl J Med 1972;287:1013-1017.

$\checkmark 4$ Vaisrub S: Empyema in lung cancer: the cloud with a silver lining. JAMA 1973;224: 1644.

5 Minasian H, Lewis CT, Evans SJ: Influence of postoperative empyema on survival after pulmonary resection for bronchogenic carcinoma. Br Med J 1978;2:1329-1331.

$\checkmark 6$ Lawaetz O, Halkier E: The relationship between postoperative empyema and longterm survival after pneumonectomy: results of surgical treatment of bronchogenic carcinoma. Scand J Thorac Cardiovasc Surg 1980; 14:113-117.

7 Pastorino U, Valente M, Piva L, et al: Empyema following lung cancer resection: risk factors and prognostic value on survival. Ann Thorac Surg 1982;33:320-323.

$\checkmark 8$ McKneally MF, Maver C, Lininger L, et al: Four-year follow-up on the Albany experience with intrapleural BCG in lung cancer. J Thorac Cardiovasc Surg 1981;81:485-492.

$\checkmark 9$ Bakker W, Nijhuis-Heddes JM, Wever Am, et al: Postoperative intrapleural BCG in lung cancer: lack of efficacy and possible enhancement of tumour growth. Thorax 1981; 36:870-874.

10 Bakker W, Nijhuis-Heddes JM, van der Velde EA: Post-operative intrapleural BCG in lung cancer: a 5-year follow-up report. Cancer Immunol Immunother 1986;22:155-159.

$\checkmark 11$ Refaely Y, Simansky DA, Paley M, et al: Resection and perfusion thermochemotherapy: a new approach for the treatment of thymic malignancies with pleural spread. Ann Thorac Surg 2001;72:366-370.

-12 Pinto C, Marino A, Guaraldi M, et al: Combination chemotherapy with mitoxantrone, methotrexate, and mitomycin (MMM regimen) in malignant pleural mesothelioma: a phase II study. Am J Clin Oncol 2001;24:143147.

-13 Chang MY, Sugarbaker DJ: Innovative therapies: intraoperative intracavitary chemotherapy. Thorac Surg Clin 2004;14:549-556.

14 Tilleman TR, Richards WG, Zellos L, Johnson BE, Jaklitsch MT, Mueller J, Yeap BY, Mujoomdar AA, Ducko CT, Bueno R, Sugarbaker DJ: Extrapleural pneumonectomy followed by intracavitary intraoperative hyperthermic cisplatin with pharmacologic cytoprotection for treatment of malignant pleural mesothelioma: a phase II prospective study. J Thorac Cardiovasc Surg 2009;138: 405-411.
15 Tohda Y, Iwanaga T, Takada M, et al: Intrapleural administration of cisplatin and etoposide to treat malignant pleural effusions in patients with non-small cell lung cancer. Chemotherapy 1999;45:197-204.

16 Shoji T, Tanaka F, Yanagihara K, et al: Phase II study of repeated intrapleural chemotherapy using implantable access system for management of malignant pleural effusion. Chest 2002;121:821-824.

17 Su WC, Lai WW, Chen HH, et al: Combined intrapleural and intravenous chemotherapy, and pulmonary irradiation, for treatment of patients with lung cancer presenting with malignant pleural effusion: a pilot study. Oncology 2003;64:18-24.

18 Matsuzaki Y, Edagawa M, Shimizu T, et al: Intrapleural hyperthermic perfusion with chemotherapy increases apoptosis in malignant pleuritis. Ann Thorac Surg 2004;78: 1769-1772, discussion 1772-1773.

19 Jones DR, Taylor MD, Petroni GR, Shu J, Burks SG, Daniel TM, Gillenwater HH: Phase I trial of intrapleural docetaxel administered through an implantable catheter in subjects with a malignant pleural effusion. J Thorac Oncol 2010;5:75-81.

20 Fitzpatrick DR, Peroni DJ, Bielefeldt-Ohmann $\mathrm{H}$ : The role of growth factors and cytokines in the tumorigenesis and immunobiology of malignant mesothelioma. Am J Respir Cell Mol Biol 1995;12:455-460.

21 Fitzpatrick DR, Bielefeldt-Ohmann H, Himbeck RP, et al: Transforming growth factorbeta: antisense RNA-mediated inhibition affects anchorage-independent growth, tumorigenicity and tumor-infiltrating T-cells in malignant mesothelioma. Growth Factors 1994;11:29-44.

22 Jarnicki AG, Fitzpatrick DR, Robinson BW, et al: Altered CD3 chain and cytokine gene expression in tumor infiltrating $\mathrm{T}$ lymphocytes during the development of mesothelioma. Cancer Lett 1996;103:1-9.

23 Lew F, Tsang P, Holland JF, et al: High frequency of immune dysfunctions in asbestos workers and in patients with malignant mesothelioma. J Clin Immunol 1986;6:225-233.

24 Kagan E: The alveolar macrophage: immune derangement and asbestos-related malignancy. Semin Oncol 1981;8:258-267.

25 Henderson DW, Attwood HD, Constance TJ, et al: Lymphohistiocytoid mesothelioma: a rare lymphomatoid variant of predominantly sarcomatoid mesothelioma. Ultrastruct Pathol 1988;12:367-384.

26 Astoul P, Viallat JR, Laurent JC, et al: Intrapleural recombinant IL-2 in passive immunotherapy for malignant pleural effusion. Chest 1993;103:209-213.

27 Christmas TI, Manning LS, Garlepp MJ, et al: Effect of interferon-alpha 2a on malignant mesothelioma. J Interferon Res 1993;13:9-12.

28 Boutin C, Nussbaum E, Monet I, et al: Intrapleural treatment with recombinant gammainterferon in early stage malignant pleural mesothelioma. Cancer 1994;74:2460-2467.
29 Boutin C, Viallat JR, Van Zandwijk N, et al: Activity of intrapleural recombinant gamma-interferon in malignant mesothelioma. Cancer 1991;67:2033-2037.

30 Douillard JY, Boutin C, Bignon J, Guerin JC, Van Derschueren R, Brandely M: Intrapleural recombinant human gamma interferon ( $r h \gamma$ IFN) in the treatment of malignant pleural mesotheliomas. Proc ASCO 1992;11:307.

>31 Yanagawa H, Haku T, Hiramatsu K, et al: Intrapleural instillation of interferon gamma in patients with malignant pleurisy due to lung cancer. Cancer Immunol Immunother 1997;45:93-99.

>32 Goey SH, Eggermont AM, Punt CJ, et al: Intrapleural administration of interleukin 2 in pleural mesothelioma: a phase I-II study. Br J Cancer 1995;72:1283-1288.

$\checkmark 33$ Sartori S, Tassinari D, Ceccotti P, et al: Prospective randomized trial of intrapleural bleomycin versus interferon alfa-2b via ultrasound-guided small-bore chest tube in the palliative treatment of malignant pleural effusions. J Clin Oncol 2004;22:12281233.

34 Yamaguchi Y, Miyahara E, Oshita A, et al: Locoregional immunotherapy of malignant effusion from colorectal cancer using the streptococcal preparation OK-432 plus interleukin-2: induction of autologous tumorreactive CD4+ Th1 killer lymphocytes. Br J Cancer 2003;89:1876-1884.

35 Ikehara M, Oshita F, Suzuki R, et al: Phase II study of OK-432 intrapleural administration followed by systemic cisplatin and gemcitabine for non-small cell lung cancer with pleuritis carcinomatosa. J Exp Ther Oncol 2004;4:79-83.

36 Ren S, Terman DS, Bohach G, et al: Intrapleural staphylococcal superantigen induces resolution of malignant pleural effusions and a survival benefit in non-small cell lung cancer. Chest 2004;126:1529-1539.

37 Wivel NA, Wilson JM: Methods of gene delivery. Hematol Oncol Clin North Am 1998; 12:483-501.

38 Curiel DT, Pilewski JM, Albelda SM: Gene therapy approaches for inherited and acquired lung diseases. Am J Respir Cell Mol Biol 1996;14:1-18.

39 Nagy JA, Shockley TR, Masse EM, et al: Systemic delivery of a recombinant protein by genetically modified mesothelial cells reseeded on the parietal peritoneal surface. Gene Ther 1995;2:402-410.

40 Yang L, Hwang R, Pandit L, et al: Gene therapy of metastatic pancreas cancer with intraperitoneal injections of concentrated retroviral herpes simplex thymidine kinase vector supernatant and ganciclovir. Ann Surg 1996;224:405-414, discussion 414-417.

41 Batra RK, Olsen JC, Hoganson DK, et al: Retroviral gene transfer is inhibited by chondroitin sulfate proteoglycans/glycosaminoglycans in malignant pleural effusions. J Biol Chem 1997;272:11736-11743. 
42 Monahan PE, Samulski RJ: AAV vectors: is clinical success on the horizon? Gene Ther 2000;7:24-30.

43 Zhang WW: Development and application of adenoviral vectors for gene therapy of cancer. Cancer Gene Ther 1999;6:113-138.

$\checkmark 44$ Yeh P, Perricaudet M: Advances in adenoviral vectors: from genetic engineering to their biology. FASEB J 1997;11:615-623.

-45 Wold WS, Doronin K, Toth K, et al: Immune responses to adenoviruses: viral evasion mechanisms and their implications for the clinic. Curr Opin Immunol 1999;11:380386.

-46 Smythe WR, Hwang HC, Amin KM, et al: Use of recombinant adenovirus to transfer the herpes simplex virus thymidine kinase (HSVtk) gene to thoracic neoplasms: an effective in vitro drug sensitization system. Cancer Res 1994:54:2055-2059.

-47 Brody SL, Jaffe HA, Han SK, et al: Direct in vivo gene transfer and expression in malignant cells using adenovirus vectors. Hum Gene Ther 1994;5:437-447.

-48 Esandi MC, van Someren GD, Vincent AJ, et al: Gene therapy of experimental malignant mesothelioma using adenovirus vectors encoding the HSVtk gene. Gene Ther 1997;4: 280-287.

-49 Batra RK, van Someren GD, Vincent AJ, et al: Adenoviral gene transfer is inhibited by soluble factors in malignant pleural effusions. Am J Respir Cell Mol Biol 2000;22: 613-619.

-50 Sterman DH, Treat J, Litzky LA, et al: Adenovirus-mediated herpes simplex virus thymidine kinase/ganciclovir gene therapy in patients with localized malignancy: results of a phase I clinical trial in malignant mesothelioma. Hum Gene Ther 1998;9:10831092.

51 Chesnoy S, Huang L: Structure and function of lipid-DNA complexes for gene delivery. Annu Rev Biophys Biomol Struct 2000;29: 27-47.

-52 Nagamachi Y, Tani M, Shimizu K, et al: Suicidal gene therapy for pleural metastasis of lung cancer by liposome-mediated transfer of herpes simplex virus thymidine kinase gene. Cancer Gene Ther 1999;6:546-553.

53 Hortobagyi GN, Ueno NT, Xia W, et al: Cationic liposome-mediated E1A gene transfer to human breast and ovarian cancer cells and its biologic effects: a phase I clinical trial. J Clin Oncol 2001;19:3422-3433.

54 Tiberghien P: Use of suicide genes in gene therapy. J Leukoc Biol 1994;56:203-209.

55 Mesnil M, Yamasaki H: Bystander effect in herpes simplex virus-thymidine kinase/ganciclovir cancer gene therapy: role of gapjunctional intercellular communication. Cancer Res 2000;60:3989-3999.

-56 Elshami AA, Saavedra A, Zhang H, et al: Gap junctions play a role in the 'bystander effect' of the herpes simplex virus thymidine kinase/ganciclovir system in vitro. Gene Ther 1996;3:85-92.
57 Pope IM, Poston GJ, Kinsella AR: The role of the bystander effect in suicide gene therapy. Eur J Cancer 1997;33:1005-1016.

58 Kolls J, Freeman S, Ramesh R, Marroqi A, Weinacker A, Summer W, Schwarzenberger $\mathrm{P}$ : The treatment of malignant pleural mesothelioma with gene modified cancer cells: a phase I study. Am J Respir Crit Care Med 1998;157:A563.

59 Schwarzenberger P, Harrison L, Weinacker A, et al: Gene therapy for malignant mesothelioma: a novel approach for an incurable cancer with increased incidence in Louisiana. J La State Med Soc 1998;150:168-174.

60 Harrison LH Jr, Schwarzenberger PO, Byrne PS, et al: Gene-modified PA1-STK cells home to tumor sites in patients with malignant pleural mesothelioma. Ann Thorac Surg 2000;70:407-411.

-61 Schwarzenberger P, Byrne P, Gaumer R, Norton J, Harrison L, Marrogi A, Kolls JK: Treatment of mesothelioma with genemodified PA1STK cells and ganciclovir: a phase I study. Cancer Gene Ther 2011;18: 906-912.

62 Smythe WR, Hwang HC, Elshami AA, et al: Treatment of experimental human mesothelioma using adenovirus transfer of the herpes simplex thymidine kinase gene. Ann Surg 1995;222:78-86.

63 Smythe WR, Kaiser LR, Hwang HC, et al: Successful adenovirus-mediated gene transfer in an in vivo model of human malignant mesothelioma. Ann Thorac Surg 1994;57: 1395-1401.

64 Hwang HC, Smythe WR, Elshami AA, et al: Gene therapy using adenovirus carrying the herpes simplex-thymidine kinase gene to treat in vivo models of human malignant mesothelioma and lung cancer. Am J Respir Cell Mol Biol 1995;13:7-16.

65 Elshami AA, Kucharczuk JC, Zhang HB, et al: Treatment of pleural mesothelioma in an immunocompetent rat model utilizing adenoviral transfer of the herpes simplex virus thymidine kinase gene. Hum Gene Ther 1996;7:141-148.

66 Molnar-Kimber KL, Sterman DH, Chang M, et al: Impact of preexisting and induced humoral and cellular immune responses in an adenovirus-based gene therapy phase I clinical trial for localized mesothelioma. Hum Gene Ther 1998;9:2121-2133.

-67 Sterman DH, Molnar-Kimber K, Iyengar T, et al: A pilot study of systemic corticosteroid administration in conjunction with intrapleural adenoviral vector administration in patients with malignant pleural mesothelioma. Cancer Gene Ther 2000;7:1511-1518.

68 Leong CC, Marley JV, Loh S, et al: The induction of immune responses to murine malignant mesothelioma by IL-2 gene transfer. Immunol Cell Biol 1997;75:356-359.

69 Addison CL, Braciak T, Ralston R, et al: Intratumoral injection of an adenovirus expressing interleukin 2 induces regression and immunity in a murine breast cancer model. Proc Natl Acad Sci USA 1995;92: 8522-8526.
70 Mukherjee S, Haenel T, Himbeck R, et al: Replication-restricted vaccinia as a cytokine gene therapy vector in cancer: persistent transgene expression despite antibody generation. Cancer Gene Ther 2000;7:663-670.

71 Rosso R, Rimoldi R, Salvati F, et al: Intrapleural natural beta interferon in the treatment of malignant pleural effusions. Oncology 1988;45:253-256.

72 Cascinu S, Isidori PP, Fedeli A, Fedeli SL, Raspugli M, Rossi A, et al: Experience with intrapleural natural beta interferon in the treatment of malignant pleural effusions. Tumori 1991;77:237-238

73 Odaka M, Sterman DH, Wiewrodt R, et al: Eradication of intraperitoneal and distant tumor by adenovirus-mediated interferonbeta gene therapy is attributable to induction of systemic immunity. Cancer Res 2001;61: 6201-6212.

74 Sterman DH, Recio A, Carroll RG, Gillespie CT, Haas A, Vachani A, et al: A phase I clinical trial of single-dose intrapleural IFN-beta gene transfer for malignant pleural mesothelioma and metastatic pleural effusions: high rate of antitumor immune responses. Clin Cancer Res 2007;13:4456-4466.

75 Sterman DH, Recio A, Haas AR, Vachani A, Katz SI, Gillespie CT, et al: A phase I trial of repeated intrapleural adenoviral-mediated interferon-beta gene transfer for mesothelioma and metastatic pleural effusions. Mol Ther 2010;18:852-860

76 Sterman DH, Haas A, Moon E, Recio A, Schwed D, Vachani A, et al: A trial of intrapleural adenoviral-mediated interferon-alpha2b gene transfer for malignant pleural mesothelioma. Am J Respir Crit Care Med 2011;184:1395-1399.

-77 Selvaraj P, Yerra A, Tien L, Shashidharamurthy R: Custom designing therapeutic cancer vaccines: delivery of immunostimulatory molecule adjuvants by protein transfer. Hum Vaccin 2008;4:384-388.

78 Vachani A, Moon E, Wakeam E, Albelda SM: Gene therapy for mesothelioma and lung cancer. Am J Respir Cell Mol Biol 2010;42: 385-393.

79 Giuliano M, Catalano A, Strizzi L, et al: Adenovirus-mediated wild-type p53 overexpression reverts tumourigenicity of human mesothelioma cells. Int J Mol Med 2000;5: 591-596.

80 Dong M, Li X, Hong LJ, Xie R, Zhao HL, Li $\mathrm{K}$, Wang HH, Shin WD, Shen HJ: Advanced malignant pleural or peritoneal effusion in patients treated with recombinant adenovirus p53 injection plus cisplatin. J Int Med Res 2008;36:1273-1278.

81 Zhao WZ, Wang JK, Li W, Zhang XL: Clinical research on recombinant human Ad-p53 injection combined with cisplatin in treatment of malignant pleural effusion induced by lung cancer. Ai Zheng 2009;28:13241327. 